\title{
Gendering the Phallic Gaze: Masculinity, Body and the Erotic Spectacle
}

\author{
Amartya Karmakar
}

Department of English Language and Literatures, University of Calcutta, India

Received: 04 May 2021; Received in revised form: 01 Jun 2021; Accepted: 12 Jun 2021; Available online: 21 Jun 2021 (C)2021 The Author(s). Published by Infogain Publication. This is an open access article under the CC BY license (https://creativecommons.org/licenses/by/4.0/).

\begin{abstract}
The paper attempts to present a feminist critique of the theory of gaze and its consequence in the representation of gender and sexual difference in western culture's phallogocentric discourse and the privilege to masculine vision that this discourse asserts in the construction of the feminine body as passive, erotic and corporeal. The purpose of this study is to elaborate on the patriarchal ways of seeing, highlighting the role that vision plays in the masculine production and propagation of the feminine corporeal body, predominant in the visual and textual language fabricated in an androcentric society.
\end{abstract}

Keywords-Erotic Spectacle, Female Sexual Body, Male Gaze, Politics of Power, Sexual Difference, Theory of the Gaze.

\section{INTRODUCTION}

The obsessive 'pre-occupation with the visual' Rey Chow indicates, 'inform the very ways social difference - be it in terms of class, gender or race - is constructed' (Chow, 1992, 101). Representations are predominantly ruled by masculine vision or the male gaze responsible for the social, cultural and political construction of the self as well as its counterpart - an object to be acted upon, irrational in its intellect, inherently passive, innately powerless; to be protected or exploited as the masculine subject wants. Feminist social historians have demonstrated that women throughout history have been allotted the role of the Other. As Genevieve Lloyd famously diagnosed: historical and cultural conceptions have symbolically associated Reason as male, establishing a binary of maleness as analogous to a clear, determinate mode of thought and femaleness as vague and indeterminate. According to her, in historical and traditional Greek thought, Man's role as the active became central to creating new life and restricted the role of the woman into nourishing the life thus produced (Lloyd, 1989, 2-3). Elizabeth Grosz elaborates on Plato's belief of the limited roleof women as a mother, designating them as passive in the process of creation:
$[\mathrm{M}]$ aternity is regarded as a mere housing, receptacle, or nurse of being rather than a coproducer, distinguished matter or body from form, and in the case of reproduction, he (Plato) believed that the mother provided the formless, passive, shapeless matter which, through the father, was given form, shape, and contour, specific features and attributes it otherwise lacked. (Grosz, 1994, 5)

It is through the Father, said Plato, as the active-masculine in the reproductive process that matter was transformed from a formless object to a definite being, from meaninglessness to a specific entity with meaning; the mother's role was to house this formless matter until ready. In early civilization and primitive culture, the male's physical abilities, writes Lerner, attributed towards making him the central Father figure - thehunter, the protector, the defender; the 'defended' was the woman whose biological-deterministic subjection destined her for the role of the mother. By attributing these gendered roles based on biology (or on Man-the-hunter's greater physical strength), he 'protects and defends the more vulnerable female, whose biological equipment destines her for motherhood and nurturance' (Lerner, 1986, 17) in a cultural system ruled by androcentric ideology. With 
institutionalization among human societies, the female role within this sexual imbalance was never redefined, never restored to a position of equality. Gender dictated through masculine ideologies became accountable for the historical invisibility of women.

The binaries of active/passive, mind/body, subject/object dichotomy distinguish between the masculine and the feminine through the socio-cultural roles they take up within the society; a society where the privilege of seeing is pivotal in generating a hierarchy between the one who observes and the one who is observed. The social construction of the binary system attributes normativity to men as the active-subject whose drives are purely intellectual in contrast to women identified as a corporeal passive-object of being. The first part of this paper analyzes these very dichotomies of representation to understand the role of the masculine in the reproduction of the 'body' as feminine. What is central to my argument is an analysis of the ways of seeing that is based upon the phallic model where the privilege of male gaze, when set upon the female body, sexualizes it to the point where it loses its identity and acts as 'the obliging prop for the enactment of the man's fantasies' (Irigaray, 1985, 25). The social and political aspects of Sartre's phenomenology and Foucault's critique of modern society provide us with interesting insights into the role of power in the construction of gender and its representation in an era that is preoccupied with the visual. Within this context, the loss of sight is the loss of one's position in an authoritative phallic model which is responsible for constructing the subjects, the hierarchical social structures, as well as the binaries that are prevalent within these structures. The 'Eye' as a substitute as well as a symbol for the phallic code organizes how the female body within the heterosexual mode-of-conduct is created and subsequently perceived. In a social setup inherently patriarchal, female identity and independent consciousness are replaced by a corporeal body - flesh and being - eroticized for male pleasure. This is another perspective this paper presents - a study of the female body within the substructures of these binaries created by the masculine production of art. Polarities of representation disseminate the female body as a signifier of the erotic desire produced by and under the masculine gaze. The mind/body, active/passive, subject/object dichotomies highlight the erotic body as a centralized site of visual investigation, which diminishes the woman's role in a text from a state of a passive object to a body regulated as a passive object-of-desire.

\section{Is the Gaze Phallic?}

In what might be considered a play on the Promethean myth of punishment, Stephen Dedalus, the protagonist and alter-ego of Joyce, is threatened with castration in the opening pages of the text. What surprises us is the nature of this castration. He has to ask for forgiveness from his mother and remain within the confines; the forgiveness comes as a sort of repression that disallows the artist from transgressing the policies of the law set on him by his society. He must choose to be civil, apologize or face the horror of his eyes being pulled out by eagles. Castration, or the loss of the phallus, is displaced here by the symbolic threat through the loss of Stephen's 'eyes', a crucial and necessary component of the artist. Within the first pages, and throughout this self-portrait, Stephen is challenged by phallic modes of power and authority that he must resist and subvert if he is to evolve from a young man to an artist. For Stephen, the emasculating threat is more a challenge to restrain the individual from transgressing the law than it is of a loss of manliness; castration here is the loss of sight, an intimidation of sudden blindness that ruptures artistic vision.

In The Uncanny, Freud refers to blinding as a punishment similar to castration where Oedipus' blinding is symbolic of castrating himself for his mythical law-breaking sin. Oedipus' loss of sight indicates that his privilege to see is taken away from him. This visual loss is an admissible source of anxiety that Freud compares with the threat imposed upon the individual with the fear of losing the phallus:

A study of dreams, phantasies and myths has taught us that a morbid anxiety connected with the eyes and with going blind is often enough a substitute for the dread of castration. (Freud, 2001, 160)

Freud's argument on the 'substitutive relation between the eye and the male member' (Freud, 160) points us toward an elementary connection between the phallic model of power and the act of seeing. In relating vision with the phallic organ, Freud makes a critical analogy that is useful in understanding heterosexual gender construct and the problems with 'seeing' in the representation of the female body. The eyes function as a substitute for the male organ, damage to which results in a form of castration anxiety that poses the terror of impotence, of powerlessness, of loss of identity and thereby the threat of losing one's position from the dominant political and social structure. Stephen faces the same; the menacing rhythmic and repetitive 'pull out his eyes, apologise' (Joyce, 2004, 4) horrifies him, it engenders the artist with the threat of neutralization, of leaving him powerless; impotence that induces fright of literary blindness. For Oedipus, blinding is a relief from shame, it is a desperate self-inflictive attempt at unburdening himself from his guilt of breaking 
the Law of the father. While literal castration might have killed him, blinding renders him more impotent and is a befitting conclusion, according to Freud, and 'the only punishment that was adequate for him by the lextalionis' (Freud, 160). Seeing, culturally and politically, is a masculine act, and is a privilege reserved for men; the eyes are symbolic of the phallic power, a privilege that women are denied due to their lack of a visible phallus.

For LuceIrigaray, there is a definitive relation between the eye and the phallus as a master-signifier (Irigaray, 1985, 60). In her Speculum of the Other Woman, she argues that identity in a phallocratic society is dependent on the presence or the absence of the phallus. Women are defined through their lack: 'Nothing to be seen is equivalent to having no thing. No being and no truth.' (Irigaray, 48). She insists that in comparison to the male subjects and its presence of a phallus, women fail to demonstrate a 'thing' that can visually assert the female's position as equal to that of the male in a phallocratic domain. It is within this domain that, subjected to be socially and culturally inferior, women are reified as castrated. As the woman-asOther is suppressed by the authoritative voice of the malesubject (establishing himself within this domain as the superior subject) he now produces as well as controls the gaze. As the 'Other', produced and practised by the patriarchal juridical system, women are thus kept excluded from all areas of life diminishing all opportunities for active participation. Phallic discourse, ruled by the dominant ideology of the master-signifier, contorts female identity, ultimately negating the active presence, limiting her social role in writing practices to only as accessories to the male-subject. She is, as represented through the masculine vision, forced into the role of the Other - a being always secondary in its significance, forever negligible in the part she takes up in a patriarchal world.

Gilbert and Gubar refer to the male pen as a metaphorical penis. ${ }^{1}$ In their reading of the social, political and cultural structure, this pen is also the law of the Father. In the production of art, Gilbert and Gubar highlight, male sexuality holds key to the mastery over literary and visual power. It is through this metaphorical penis (access to which is advertently denied to women) - the masculine hegemonic 'eyes'- that the world is constructed, and eventually perceived, not as it is or should be, but as the masculine perception of the world constructs it to be.

${ }^{1}$ See Gilbert and Gubar's 'The Madwoman in the Attic' where they compare literary paternity and male artistic supremacy (represented symbolically by the pen) with the metaphorical penis, by drawing on an analogy between male sexuality, literary power and masculine authority over male authored text, negating the woman's role as a creator.
Sight, then, plays a crucial role in creating the world both visually and textually; more specifically, sight perceives the human subject. Seeing comes before words, Berger writes, as we look to establish relations between us and our surroundings (Berger, 1972, 8). Of significance here is the feminist scholarship that has pointed out the tradition of representations and reconstructions of the world in literary and visual forms where vision or the hegemonic 'eyes of the man' construct a world in which the primary subject is masculine; reducing the role of the woman to that of the secondary subject - an object.

Phallic gaze is a masculine privilege that outcasts womanas-body in contrast to man-as-mind as well as functions as an instrument of power that can dictate discourse and transform it into a language that validates for the existence of only the singular, male-specific, master discourse. The phallic gaze is also invested fundamentally in the construction of subjects and objects and the subsequent binarized gendering of these very subjects and objects as either masculine or feminine. Further investigation into the phallic model constructed around gender leads us to articulate a theory of the gaze that sees the female body as a center of inscripted desires; it is seen as a blank canvas where male fantasies and desires can be inscribed to materialize the corporeal body into a consumable product of mass culture.

\section{BINARIES OF REPRESENTATION}

\subsection{The Other as the Passive Object}

Simone de Beauvoir draws from the Hegelian dialectic of consciousness in a master-slave relationship to explain the oppressive forces in social relations that ascribe women to the role of the Other. In a long-standing struggle to exert dominance over one another (a metaphorical fight todeath) a conclusion of certainty, explains Beauvoir, can only be reached by the subject's negation of the Other. Through this process where one must invalidate the other, the supremacy of the subject's triumph is established by mutual recognition of the 'Subject' as the superior conscious and the repressed as an objectified, alienated 'Other':

[A] fundamental hostility to any other consciousness is found in consciousness itself; the subject posits itself only in opposition; it asserts itself as the essential and sets up the other as inessential, as the object. (de Beauvoir, 1949, 7)

By the subject's paternalizing role in configuring the essential and the inessential, it commands over the linguistic and the visual, regulating it against the feminine subject; the masculine subject's construction as it 
perceives the female-subject formulates a form of oppression that is embodied in the heterosexual gendered division. As muses or literary subjects in male-authored texts, the female serves as a device that instates the absolute authority of the male writer over his female subject. One of the chief sources of oppression, as Rey Chow points out, is the way that objects/women are 'consigned to visuality' (Chow, 1992, 105). In the context of gendered differentiation, textual and visual representations evidently provide facts to demonstrate that 'seeing' is definitive in the process of the socio-cultural formation of gender - women appear in these representations as erotic objects of desire; as gaze objects that function towards appealing to the male perceiver. Gaze, or scopophilia, thus, dictate the terms of representation as a politicized tool that carries the ability to neutralize the Other:

Nothing could better serve the paternal superego than to reduce masculine vision completely to the terms of power, violence, and control, to make disappear whatever in the male gaze remains outside the patriarchal, and pronounce outlawed, guilty, damaging, and illicitly possessive every male view of woman.(Snow, 1989, 31)

Her identity, her destiny, her position in the society are narrowed down to what can be referred to as the negative of the masculine - feminine sexual identity is defined in relation to, and by the phallocratic ideology of the 'master discourse'. Thus, the woman's identity under the totalitarian, authorial gaze of the male is interpreted through the absence or lack that, in comparison, masculinity posits itself with. Under this regime of structured gender domination, the patriarch's gaze colludes with the identity of the feminine to construct the masculine as superior to the other half:

[W]omen have served all these centuries as looking-glasses possessing the magic and delicious power of reflecting the figure of man at twice its natural size.(Woolf, 32, 1993)

With modern technological advancements, visuality has been vitally significant in the construction and division of sexuality into two classes - the masculine and the feminine, or, the signifying phallus versus its deficit. Photographic representations now allow for the depiction of women as the erotically charged object whose elemental importance within the photographic image is the semiotic transference of passivity of feminine sexuality or to offer the body as an object of possession. As a gendered identity within the frames of a photographic image, this female-asobject's sole meaning comes from the meaning ascribed to it by the subject. It operates within the boundaries set upon it by the masculine gaze. The cultural projection of the feminine image created by the man-as-subject is regulated by this controlling gaze. She is trapped within the space she occupies with her body, a space that is specifically designed to be penetrated by the gaze. The privilege of vision that allows the male-subject to produce the gaze in the first place and reduce the female-subject to that of the Other plays a crucial role in our understanding of the formation of gender as identity and the attributed qualities associated with it. For the gaze to function in a subjectobject binary, the subject's 'look' requires the object to be at the locus of this look - an analysis of visual discourse demonstrates that she is at the center of the space she inhabits in order for the gaze to operate. As the 'bearer of the look', (Mulvey, 715, 2009) he regulates her by regulating the body, denying her to escape her objecthood. The feminine body under the male gaze becomes the site of aesthetic, economic, epistemic, cultural, philosophical and political inquiry. Passivity comes from the body's positionality in its confinements. But what makes the female body, in a patriarchal setup, a passive object in contrast to the male body?

\subsection{Woman as Body}

Peter Brooks points to the social difference in the representation of the masculine and the feminine body:

It appears that in patriarchal societies, the male body is ostensibly deproblematized, decathected as an object of curiosity or of representation, and concomitantly more thoroughly hidden. There is an apparent paradox here: if the male body in patriarchy becomes the norm, the standard against which one measures otherness-and thus creates the enigma of woman-one might expect the male body to be more openly displayed and discussed. But a moment's reflection allows us to see that the paradox is merely apparent. (Brooks, 1993, 15)

As Brooks asserts, masculine erotic gaze has, since the Renaissance, marked the cultural female body as a 'smooth surface', reworking the feminine body as a model of representation that is distinctly dissimilar to the male body - the feminine body is caught at moments that invade privacy, they are sought when they are mostly unaware of the presence of a seer. He further argues that the construction of the male body is heroic, evidently staged, represented in 'postures of action, combat, or struggle, its muscles tensed and visible' (Brooks, 16-17). In narratives, gender works in an apparently perplexing way: the hero is the male ideal that reflects the patriarchal ideology; a phallic figure defined through its transcendental abilities. In contrast, the female body is inefficient, unable to 
transcend the corporeality of its being. Joseph Campbell's observation validates the authoritative perspective within a masculine narrative where:

Woman in the picture language of mythology represents the Totality of what can be known. The hero is the one who comes to know. (Campbell, 1969, 116)

The female-subject in this hero's narrative functions as a vehicle that merely plays the role of an accessory in the hero's self-realizing journey towards the fulfilment of his destiny. Her body represents an epistemic value that the male hero ventures to discover within his journey, but her corporeity means that she belongs to an inferior state when compared to the male hero whose sublime ability marks him as the superior power in the narrative. Patriarchal poetics fashion these narratives according to the prevalent gender relations where women are marginalized into nonbeings, without subjectivity, without voice, denying their choice of the political and cultural depiction of the body and the representation of the self. Brooks' paradox can be further elaborated from comparisons between the male and the female body to the paradox of women occupying the secondary role in plots whilst being the central erotic object constructed for male pleasure. The secondary role in narratives(reserved particularly for women) have been exploited by the over-exposing of the passive female figure as a corporeal body defined through its sexuality under male scrutiny. The feminine body is thus reduced to a 'docile' being - 'subjected, used, transformed and improved' (Foucault, 1991, 180) to make it more appealing to the male viewer. This body is controlled by what produces it and the consequent differences are regulated essentially by a society that is determined by a patriarchal ideology of heterosexual division. In an androcentric society, gender is divided into and limited to the masculine-feminine binary where the systematic construction of the feminine as repressed allows the masculine to act as the all-powerful subject. As Butler demonstrates through her reading of Foucault, the politically dominant ideology produces subjects that are immanently under the control of the law that produce them:

Foucault points out that juridical systems of power produce the subjects they subsequently come to represent. Juridical notions of power appear to regulate political life in purely negative terms... But the subjects regulated by such structures are, by virtue of being subjected to them, formed, defined, and reproduced in accordance with the requirements of those structures. (Butler, 1999, 2-3)
As the Other, the female body is designed as a system of ontologico-carnal meanings that is devoid of consciousness or the ability to participate in a masculine domain; in the Cartesian mind-body dichotomy, the subject's contact with the Other is registered through the symbolic murder of the female-subject's identity and is replaced by the identity that the male-subject creates for the Other; a process of Othering which allows for the existence of the Other within the specified realms created by the masculine. In other words, the subject's gaze transforms, destroys, and recreates the entire system of meanings to construct the Other as a new species, a nonidentity invented by the hegemonic imposition of the masculine ideals. Depersonalization of the Other through the subject's hegemonic gaze results in the feminine body taking the center-stage, the eyes that perceive the body become the 'eye of power'. The corporeal body, which is revealed to us through the eyes, become radically demarcated through a set of customs: social, cultural, political and sexual that govern the production and perception of the Other. By taking control of the Other's body, it is commodified into a sexual being defined by its passivity to act, to take control over itself. A study of the masculine subject's relationship with the Other, established by a politics of gaze, suggest the role that masculine privilege of vision offers in creating and dominating the female sexual body in social communication.

\section{SARTRE AND FOUCAULT: BODY, POWER AND PATRIARCHY}

The material feminine body, translated within patriarchal productions, is perceived as the object of male fetishistic and scopic drive. The masculine 'look' responsible for the cultural construction of the female body as a product of the gaze elucidates the point of difference between sexes - a difference that is now normative behavior in social and textual practices. Narratives produced by male subjects and concerning itself with a masculine hero consciously restructure the self by invalidating the Other - in Sartrean terminology, being-for-itself annihilates the being-in-itself to exist in a plane, unchallenged. ${ }^{2}$ Sartre's subjects identify, perceive and establish their place in the world through the act of looking: 'to perceive is to look at'

\footnotetext{
${ }^{2}$ Sartre's phenomenological exploration into the nature of being distinguishes between being-for-itself (pour-soi) as consciousness against the being-in-itself (en-soi) as non-conscious things. In order to assert a consciousness as being-for-itself, it must negate the existence of the being-in-itself, thereby claiming the position of the only consciousness. Being-for-itself is associated with the active while being-in-itself is a passive object of nonconsciousness.
} 
(Sartre, 258). To assert dominance over the Other, my position with respect to the one I am looking at is of prime consequence. I can only maintain my subject-hood within the space I inhabit by seeing without being seen. By negating the subjective existence of the Other, I turn it into an object occupying my field of vision. Objectification in Sartre's philosophy constitutes itself as a system of freedoms and non-freedoms where 'I' as subject challenge the freedom of the Other by seeing it without allowing it to see me. This encounter between the subject and the Other is essentially played out through sight - seeing without being seen - it is a game of negotiations, an act of repetitive re-construction of the world around the subject to be in contention of retaining subject-hood, to be in control, always, as the producer of meaning. Central to this argument is the power relation between two individuals, where, to be seen is to be vulnerable. As a result, I am aware of myself as a subject but my awareness is threatened by the fact that there are other subjects for whom I am the object. Therefore, I must constantly struggle to keep my subject-hood intact; it comes with the cost of reducing the other, (while saving myself from) to what Luna Dolezal refers to as the 'seen' body: 'I experience my body not on my own and not as livedthrough, but as it is reflected in the experience of it by others;' (Dolezal, 2012, 13). The seen body is what I present for the world to see. An awareness of being turned into the Other at any moment I come in contact with another subject makes me turn the Other as the seen object occupying my field of vision. Since my subjectivity allows me to transform the Other into a gendered subject, creating binaries of masculine and feminine can be achieved by administering the phallic gaze over the Other's unified body. By containing and modifying the body, it can be revised and improvised to follow the Law of the phallic discourse that operates on the feminine body by definition of its corporeity. As gaze-subjects, men neutralize women in similar ways - by disallowing subjectivity, by defining them as the social 'Other', by imposing their hegemonic jurisdiction over the representation of the body in literary and film texts as an object of desire, conforming femininity with an idealized notion of erotic sexuality. For Sartre, the gaze-object at the other end of the look is the feminine body; he defines femininity with 'everything that gapes open' (Sartre, 613), reducing her form to a body with a hole.Sartre further professes his claim of the masculine subject's voyeuristic gaze:

All these images insist that the object is ignorant of the investigations and the instruments aimed at it; it goes about its business without noticing the glance which spies on it, like a woman whom a passerby catches unaware at her bath ... We speak of snatching away her veils from nature, of unveiling her ... Every investigation implies the idea of a nudity which one brings out into the open by clearing away the obstacles which cover it, just as Actaeon clears away the branches so that he can have a better view of Diana at her bath. (Sartre, 578)

Sartre's position in respect to the theory of gaze he posits is unashamedly sexist; the object of the gaze is a nude female body caught unaware, investigated as an object of non-consciousness occupying the field of vision through the body. Sartre identifies being-for-itself with the mind and constructs the being-in-itself as the feminine body which poses a threat to the consciousness of the being-foritself. As Collins and Pierce (1980) observe, the female anatomy for Sartre consists of the threatening being-initself with its holes and slime; the objectified, seen body is both disgustful and erotic in its nudity. In ascribing the foritself with the masculine and the in-itself as the passive, feminine body of non-consciousness, Sartre follows the archetypal tradition of a mind-body dichotomy that allows for the female body to exist as an object of desire, a 'hole' presented as 'a nothingness "to be filled" with my own flesh' (Sartre, 613). He further disintegrates the female body into 'holes and slime', an appeal to the for-itself, that presents a death to the consciousness. He evidently, and very adeptly, works to establish a way of looking that reduces the female body as a thing to be devoured, a body of smooth whiteness that must be consumed, holes that must be filled; Sartre eroticizes the body to neutralize it, to transform it into the in-itself that will be conquered by the masculine flesh, that will be reduced to a passive-object whose performance is solely dependent on the appeasement of the masculine look.

On the other hand, Foucault's study of the gaze directs to the role of power in social space. Even with Foucault's failure to recognize sexual difference or grant a discourse particular to women, Linda Williams argues: 'Foucault has often failed to acknowledge women's situation in the constitution of meaning and power in Western culture, but he still gives us the tools to ask what the articulation of sexual difference involves.' (Williams, 1989, 4) Foucault's theories must then be used for discursive feminist issues as political tools rather than direct feminist criticism.

Rigidly oppressed by an obedience to patriarchy, the feminine body falls prey to a hierarchy of power division that influences the body on various levels, creating various ideal models of the erotic feminine body. These 'ideals' dominate the body in its passivity; like Sartre's privilege of masculine vision, the conflict between the subject and the Other gives rise to the docile feminine body that can be 
inscribed with desires particularly directed for the male gazer. The body, for Foucault, is controlled in the panoptical structure through a method of surveillance that induces in the inmate 'a state of conscious and permanent visibility’ (Foucault, 1995, 201). It is a disciplinary mode of 'micropower' that inscribes regulatory decorum over the body. The Other's consciousness, once aware of the possibility of being seen, is left vulnerable; the Other finds itself in a space where the subject's objectifying gaze decenters the Other and leaves it in a space that is uniquely created for surveillance. As Grosz suggests:

In Foucault, the body is the object, target, and instrument of power, the field of greatest investment for power's operations ... [P]ower, according to Foucault, utilizes, indeed produces, the subject's desires and pleasures to create knowledges, truths, which may provide more refined, improved, and efficient techniques for the surveillance and control of bodies, in a spiral of power-knowledge-pleasure. (Grosz, 1994, 146)

If the female body is suppressed under a regime of patriarchal control, this body can be refined and improved to satisfy. The coerciveness of the gaze and the privilege of masculine vision along with the construction of the 'ideal erotic body' determines a compliant submission to the patriarchal hierarchy of power that induces female bodies to function precisely as bodies-without-mind. If the female body is a site of sexual conquest for Sartre, it is a site for the exercise and regulation of power for Foucault. It is a complex association that connects the body with representation following the ideologies that construct the body as sexual, governed by genitality, ruled by the production of gestures and appearances that inarguably follow the ideals that constitute the body as erotic.

For both Sartre and Foucault, the body, seen by the subject, is a decentered, gazed-at, objectified Other, entrapped within the social space inhabited by the subject. The 'look' manifested by both Sartre and Foucault's subjects are objectifying, alienating, self-evaluating, embodying shame and anxiety when the gaze-object is at the other end of the look. Our reading of these social philosophers can constitute a rather significant contribution in understanding the masculine production of art and film language and subsequent creation of the erotic body and its regulation within this language. Othering and surveillance are factors that are crucial in the establishment of power that allows the male writer/painter to dominate the discourse he represents, as well as suppress women into conformity, thus allowing for the male author and male subject to be in a position of superiority. The female body, as an agent of excitation, can never revolt or organize to become something else, something outside the hegemonic imposition of the masculine ideals that rule the feminine body.

Apart from promoting a negative image of gender and sexual difference, masculine art dominates through social oppression of the feminine body as an object in visual culture, that, in an androcentric society inscribes the body with an 'insatiable need to see the body perform erotically' (Brooks, 278). The body under the strict regimes of performance become a blank slate where power and resistance collide to create a pleasure distinctly scopic - a visual treat for the male fantasy brought out by the performance of the erotic body in its individuality or in its vulnerable interaction with the male counterpart. But the regulation here is not specific to the outside forces that control and consume the body but is also organized to work from the inside, making aware of the subject to chase the ideals that dominate visual culture. For women, norms of beauty and health exist as ideal points that must be strived towards for larger acceptance; these norms become part of their identity-system. The product of the manifestation of this male gaze is a thing to be devoured: 'to know is to devour with the eyes' (Sartre, 578), a body revealed to us through sight. Even for Sartre, as it is for Foucault, the key relationship between the observer and the observed, the active mind/eyes and the passive body is at the heart of this polarity in which the body is entrapped within the systems created by the active-subject producing the gaze. In visual societies, the bearer of the 'look' takes up the role of the masculine, modifying the object to be looked at as the feminine. Dolezal argues:

Despite the invisibility of women as social subjects, the physical aspect of female bodies has traditionally been subject to heightened scrutiny; women are expected to maintain their form, appearance, and comportment within strictly defined social parameters, or else face stigmatization and the loss of social capital. (Dolezal, 2010, 357)

Power, thus, plays a key role in this regulation, and it is through the social relationship between the binaries of representation - subject/object, active/passive, mind/body that gaze operates as an oppressive tool that disciplines the various forces at work to produce the feminine body as a body-of-desire. The panoptical form not only performs as an instrument producing 'self policing subject, a self committed to a relentless self-surveillance' (Bartky, 1988, 81 ) but also creates a tyrannical discourse that puts the corporeal body to occupy the center-stage; a stage where the ideal-female-material-body is made the locus of the masculine gaze. Thus, the body faces both internal and 
external negations to comply and remain within the phallocratic system of representation. The image of the body constructed in this system of representation, following the 'ideal' image of the social body, conforms into an erotic object that is now normalized into film texts, appropriated as a visual demonstration of feminine sexuality.

\section{THE EROTIC SPECTACLE}

Consider the following passage from Sartre's Being and Nothingness:

Let us imagine that moved by jealousy, curiosity, or vice I have just glued my ear to the door and looked through a keyhole ... This means that behind that door a spectacle is presented as "to be seen," a conversation as "to be heard." The door, the keyhole are at once both instruments and obstacles; they are presented as "to be handled with care;" the keyhole is given as "to be looked through close by and a little to one side," etc. Hence from this moment "I do what I have to do." (Sartre, 259)

The 'spectacle' beyond the obstacle is an unknown, a form of knowledge that the subject aspires for, demands, and strives toward to vanquish his curiosity. The subject is a voyeur here, a peeping-tom, consciously invested in the act of seeing through the 'keyhole'; according to Mulvey, 'whose only sexual satisfaction can come from watching, in an active controlling sense, an objectified other.' (Mulvey, 713). Phallic gaze extends a mode of seeing where the female body, being the primary site of visual investigation, is an object of desire that is created and contemplated for and by the prevailing patriarchal set-up that sees the body as the locus of the scopical drive. The humanized form of sexuality presented as an erotic spectacle is an oversexualized version of the 'ideal body' articulated as an object to be surveyed, possessed, explored, unveiled and penetrated. ${ }^{3}$ Modern visual culture's access to the naked feminine body has made the image of the erotic prevailing throughout narratives; it is a 'docile' body that is openly accessible to the inquiring gaze of the masculine subject. Berger notoriously comments on the sexual body in terms of its relation with the viewing subject:

\footnotetext{
${ }^{3}$ The penetration here is both visual and sexual, symbolic and metaphorical. The body is not only limited to being an object of the gaze, but also a 'site of contestation ... desired and sought after, sexual pleasure alters the consenting subject, deconstructing notions of will, control, coercive domination.' (bell hooks, 1992, 367).
}

What is the sexual function of nakedness in reality? Clothes encumber contact and movement. But it would seem that nakedness has a positive visual value in its own right: we want to see the other naked. (Berger, 58, my emphasis)

The naked body, for Sartre, is symbolic of 'our defenseless state as objects' (Sartre, 289). An uncovered body attracts visual attention, one that jeopardizes subjectivity and leaves the self to be objectified by the Other's look. The female, docile body, marked by its nakedness, when subjected to the same objectifying gaze, is transformed into the 'erotic spectacle' that projects, mirrors and doubles male fantasies. We want to see the other naked without being discovered, and this is where Sartre and Foucault's philosophies intersect for a better understanding of a system of micropowers operating to produce and limit the erotic object within the field of vision; a moment's notice validates that this field of vision works not unlike a frame that entraps the body and its movement, restricting it from escaping corporeity. ${ }^{4}$ Whether it is a pair of eyes looking through a keyhole or an inspector overseeing from a tower, the system works infallibly when the body is centrally placed in the field of vision, objectified and not allowed to escape the frames that entrap it. In both these apparatuses of the gaze, explicated by Sartre and Foucault, confining the body within the frames ${ }^{5}$, limit the movement, making it easier for the observer's voyeurism. When the erotic body is placed inside these frames, a patriarchal mode of oppression, power, desire take precedence; it denies the body from freeing itself. Within these spatial confines, the ideal male ego can make the entrapped body reflect its carnal desires, it can make the body unveil itself, strip down to its skin, all for the reflection of masculine pleasure. Gendered spectatorship 'dissociates power from the body ... reverses the course of the energy, the power that might result from it, and turns it into a relation of strict subjection' (Foucault, 1984, 182). The erotic spectacle is a result of this phallocentric subjection, an entire policing of the literary canon of narratives into a system of contrary dichotomies - the bearer of the 'look' against the bearer of the 'lack', or in other words, man against woman. In a world where literary and artistic productions are ruled by

\footnotetext{
${ }^{4}$ The frame here signifies, according to Jacques Derrida's 'discourse on the frame' a distinguishing element that differentiates between the 'inside' and the 'outside'. The conceptual frame manifests here a boundary that confines the body within it, demarcating the body as a photographic object; anything within a frame draws our attention to the viewing subject inside it. The screen in an auditorium or the delimiting frame of a camera act as literal borders that draw one's gaze to the viewing subject placed within it.

${ }^{5}$ The frames here refer to both Sartre's keyhole and Foucault's watchtower (Panopticon) where gaze functions through the limiting of the movement of the body within the scope of vision.
} 
the Law of the Father, women become non-entities produced by men, regulated and delineated for the consumption of the masculinist, paternalist society. Under this Law, the corporeality of the female body is coded with symbolic and ideological interpretations of the erotic - the erotic body is produced as inferior, as a lack, as non-male and simultaneously overexposed as a capitalist commodity, materialized, renovated and communicated as an embodiment of masculine desire with the purpose of commercializing the body, exciting pleasure and disseminating the notion of the idealized erotic figure, to be reproduced by the male and pursued by women. The sexual body, a highly repressed political anatomy, functions to comply and regulate within the disciplinary structures designed by men which further becomes a communicative link between the male author and the male reader. Peter Brooks highlights:

Narrators are in fact more nearly voyeurs than watchmen; ... narrative structure and theme, concern curiosity directed at the concealed, clothed, hidden body, with the concomitant suggestion that the source and meaning of the story is somehow hidden on or in that body. (Brooks, 106)

Here, we come across the idea of knowledge inscribed within the body; a body that is concealed through its clothing, mystified but ready to be uncovered. Narratives construct the hidden body through the eyes of the narrator whose function as a voyeur within the plot is to convey to the male reader the tales of the skin, excitation in the hope of seeing the body in its nakedness, or as Barthes suggests: 'an Oedipal pleasure (to denude, to know, to learn the origin and the end)' (Barthes, 1975, 10).

Let us look at Henry Miller's Sexus, a text also analyzed by Kate Millet in her monumental Sexual Politics. Ida Verlaine, one of the many conquests of the protagonist, is broken down into 'components' in this scene, into a set of signifiers that control the signified:

She had on a silk bathrobe and a pair of silk hose. As she stooped over the tub to put the towels on the rack her bathrobe slid open. I slid to my knees and buried my head in her muff. It happened so quickly that she didn't have time to rebel, or even to pretend to rebel. In a moment I had her in the tub, stockings and all. I slipped the bathrobe off and threw it on the floor ... I lay back and pulled her on top of me ... As we were drying ourselves she bent over and began nibbling at my prick. I sat on the edge of the tub and she kneeled at my feet gobbling it. After a while I made her stand up, bend over; then I let her have it from the rear.
She had a small juicy cunt which fitted me like a glove. I bit the nape of her neck, the lobes of her ears, the sensitive spot on her shoulder, and as I pulled away I left the mark of my teeth on her beautiful white ass. (Miller, 1949, 180)

Millet explores here, the tone in the language, that of 'one male relating an exploit to another male in the masculine vocabulary and with its point of view' (Millet, 1990, 5). In relation to the protagonist, Ida comes off as a powerless docile body whose objective in the scene is to illuminate male fantasy; it becomes more evident due to the place where it all happens, a bathtub (which incidentally works as a frame itself, limiting Ida's movements); as if Miller teases his male readers. The subject-object relationship is apparent here: Ida, the subject of the narrator's 'exploit' functions as a passive object that is acted upon, represented as a collection of various erotic attributes that systematically work together not only in relation to one another but as stand-alone-pieces of the body meant to excite pleasure; fulfilment comes in the erotic investigative deconstruction of the female body into pieces with desirable sexual attributes. Her passivity is poignant: her bathrobe slides open, she is pulled on top of him, and he finally 'lets her have it from the rear'. She, as fashioned by Miller, fails terribly to control her 'self' let alone the masculine narrative; her actions further contribute toward making her the insubordinate trope whose purpose is to reflect the oozing sexuality of the male protagonist. Ida is an ideal product of the gaze, manufactured in contention with the prevailing ideology of woman-as-body. Her presence is an absence of control; she appears wearing a loosely tied bathrobe and stockings that make her, according to Miller, resemble figures from Cranach's paintings. She is made up of 'a small juicy cunt', 'the nape of her neck', 'lobes of her ears', 'the sensitive spot on her shoulder' and a 'white ass'. It is a notorious play of signifiers that produce Ida not as a subject that takes an active role but as an object of passivity; her failure to take control of herself or the scene can only mean that the narrator leaves her to be exploited by his male readers.

Ida is coded for a strong visual and erotic impact; she is a conscious stylization by the narrator whose exploit is a pornographic visualization of a man-woman relationship. Her presence is to highlight the presence of the active force that exerts control over the diegesis. Mulvey writes:

The determining male gaze projects its phantasy onto the female figure, which is styled accordingly. In their traditional exhibitionist role women are simultaneously looked at and displayed, with their appearance coded for a strong visual and erotic impact so that they can be 
said to connote to-be-looked-at-ness. (Mulvey, 715)

Ida's presence within the scene is necessary to the point where she can be broken down and re-created for the pleasure of the gaze. Berger's claim that 'Men act and women appear' (Berger, 47) is discernable as Miller's narrator acts on a passive, eroticized body-without-mind whose only act is an act to 'appear'. Her ontological existence is an archetype of the passive woman, one that prevails throughout patriarchal productions to provide for the man an object to act upon. The slow but eventual dismantling of the body is a performance acted out for the reader, for whom 'denuding' is a form of philosophical inquiry that takes its foundation from the visual and epistemic exploration of the body within a narrative; denuding offers the same kind of gratification that Freud refers to as Fore-pleasure (Gefahren der Vorlust) in his Three Essays on Sexuality. He maintains that 'normal sexual aim' is endangered when one becomes preoccupied with the pleasure brought about by the scopic drive instead of copulation, a subject's fixation with the visual bears him more pleasure than physical intimacy. The Other's body under the subject's gaze is metamorphosed into a site of fantasies, blended into a moment of 'the staging of an appearance-as-disappearance' (Barthes, 10) or a life of simulacra, where fiction allows unreality to be stably real. The displaced libidinal pleasure is fulfilled through the unclothing of a body that, presented as docile, is fragmented and deliberated into being the apparatus of erotic representation.

We come across something similar to Fore-pleasure in Luis Buñuel's Cetobscur objet du désir (1977) where Conchita is an allegory living in parallel metonymic realities of existence. Introduced into a patriarchal social and cultural stricture, the alternating characters of Conchita (played by two different actors) function as participants in the scopophilic cinematic language created in Cetobscur objet du désir. The contradiction becomes evident through the purported message that Buñuel tries to feed the viewers of the film and the asserted literality that is presented behind the veil of 'obscurity'. ${ }^{6}$

Cetobscur objet du désir is Mathieu's story; a patriarch retelling a tale he has absolute authority over; his authority over the female characters in his tale is apparent. His narrative is both a transliteration of his morality and works on a level of justification of his rationality. His story is for the passengers on the train; their curiosity over the story

\footnotetext{
${ }^{6}$ William Rothman's essay 'The Obscure Object of Desire', available in The Criterion Collection interprets Conchita as 'a modern heroine who refuses, on principle, to be reduced to an object of desire'.
}

drive them from being mere listeners to active participants acting as voyeurs to the many conquests of Mathieu in his pursuit of Conchita. If Buñuel presents Conchita as a reserved, powerful seductress who doesn't belong to anyone - one whose sexual favors must be earned - she is also reduced to a gaze-object for the audience through the predatory eyes of Mathieu. His narration ensures that we, as viewers outside, are participants inside his tale who see what he sees, whose frustrations are ours, whose story demands the passengers' sympathy. An integral question is to understand what the 'object of desire' is, or the semiotic role of this object in the context of Buñuel's cinematic universe.

Mathieu's objective is to possess her, to subvert her into fulfilling his carnal desire; Conchita struggles to not become that object of desire. By not giving herself to Mathieu, by remaining a mozita (virgin), she establishes herself against the patriarchal forces that try to govern her. But, even if Conchita saves herself from giving into Mathieu's desire in the film, her presence inside the filmlanguage makes her function as the gaze-object of desire for everyone outside it. Mathieu's failure to identify the two different Conchitas make her identity arbitrary; a substitutive function of the signified. Her interchangeability creates a visual surrealism where she performs as a non-identity, surviving through her body for the viewer. The invariable male gaze ensures that the destruction of the identity is replaced by a pseudo-identity of presences marked by alternating female bodies as erotic objects.

Mathieu's eyes (which are the eyes through which the participants of his story see Conchita) play a critical role his views are absolute in understanding how Conchita turns from being a strong female character to a body whose performance is limited within the language of the scopic desire. Throughout the film, Mathieu's eyes are engaged in multiple voyeuristic activities - he looks through the transom into Conchita's room, invading a private space reserved for her. He also comes across a glass door opposite which Conchita dances naked for the tourists. In a final act of voyeuristic humiliation, he looks through the gates as Conchita makes love with another man. Her activities are surveilled through Mathieu's eyes which is the eye of the camera and in extension the spectating eyes of the audience. As E. Ann Kaplan notes:

[W]ithin the film text itself, men gaze at women, who become objects of the gaze: the spectator, in turn, is made to identify with this male gaze, and to objectify the woman on the screen: and the camera's original gaze comes into play in the very act of filming. (Kaplan, 1983, 15) 
The camera's original gaze is a mechanized framing system that holds the female body within the restrictive boundaries of the frame that it creates. Conchita's movements, her presence within Mathieu's world is monitored at all times by the gaze of the camera. It is this original gaze that is responsible for turning Conchita from an independent signifier to an objectified, sexualized signified, even as she tries to deny masculine access over her body. The two actors provide different aspects to their character; the French Carole Bouquet brings in her Gallic chic and reserve while the Spanish Ángela Molina provides a blend of vulnerability and earthy sexiness (Sanchez Vidal, 1984) that make them visually desirable to the viewer.

Mathieu's gaze operates as a substitute for the sexual coupling that is denied to him by Conchita; for Mathieu, the totalization of the sexual act is replaced by Forepleasure, by the scopophilic drive derived from gazing at the naked body of Conchita. The deferred gratification that consummation would bring and its lack thereof produces a frustration for Mathieu and his male viewers which can be satisfied by the resigned acceptance that the only way to possess Conchita is to possess her voyeuristically. Lying next to bed alongside the naked body of Conchita is the only alternative to the pleasure that he seeks throughout the film - the carnal flesh of the mozita. Even if Conchitacan preserve herself from the preying needs of Mathieu, she ultimately fails to retain her agency in a strict gendered world of Buñuel where male gaze reduces her to the (not so obscure) object of desire.

The interaction between the reader/viewer and the fetishistic object (almost always the female body) comprises the erotic epistemology in literature. As Moi suggests: 'Freudian theory posits the drive for knowledge (epistemophilia) as crucially bound to the body and sexuality' (Moi, 1989, 203). The reader's desire, the internalizing excitement he receives from looking at the female body influences the main motive behind constructing plots or scenes within a narrative where the body is exhibitioned for the appeasement of the masculine 'look'. Gratification comes, not only in the process of denuding, but in reaching to the end, unveiling until there are no obstructions left. The female body in narratives follow a similar architecture; one can almost say that often in film texts and in novelistic tradition, women are masked with clothing so that the body can be revealed through an intricate process of 'denuding'; removing the clothes to reveal what is inside. The historian Charles Pinot Duclos compares this denuding of the female body with Truth, accusing men of stripping everything off the body in the pursuit of Truth, uncovering it to de-mystify; ensuring that the body is no longer a concerning issue of curiosity or inquiry. This de-mystification, an unvanquished thirst for scrutinizing philosophical and visual study is referred to as the 'Actaeon Complex' by Sartre. It is the literal violation by sight which requires the subject to remove all obstacles barring him from viewing the unknown; driven by the motive of getting a clear look of what lies on the other side of the obstruction. If clothes are to be considered an obstruction in catching the naked body unawares, (similar to the branches for Actaeon that he must remove to look at Diana's body), the female body must be eroticized by distancing the body from what hides it.

John Berger's commentary on the tradition of European art since the Renaissance points toward a methodical operation; by drawing on Levi-Strauss's idea, Berger observes how art serves the ideological interest of the ruling class of the period. The result is a series of paintings of women who are buyable, possessed by the art-loving connoisseur and spectator for whom these paintings signify, more than their interest in art, in owning a piece of work whose subject is a desirable female figure. Owning it was buying into a piece of reality framed inside a world of its own, a possession involving possessing the central subject of this reality - a woman was a transactional commodity and an unnegotiable part of the painting. The early Impressionist Manet'sOlympia (1863), modelled on Titian's Venus of Urbino (1538) represents a courtesan; the body is at once a sexually and visually consumable object; the fact that she might be a courtesan indicates to her being 'available physically and not only visually, woman as sexuality in its abuse, as sexuality exploited.' (Bryson, 1983, 145) Even if one finds the courtesan's gaze alarming, looking at it directs our eyes to the all-white bed/body simultaneity, coexisting together. Her central posture covers almost the entirety of the space inside the frame - a figure lying on a bed with her exposed breasts and her deliberately covered genitals. The body, here, is an explorable landscape and all interpretative significance of the painting arises from the figure's relationship to its environment. The surrounding attributes from little to nothing except a contrasting play of black and white. If one was to remove the space that surrounds the courtesan, with the black cat and the African woman, the erotic figure is still at the heart of the image. Olympia's body is the painting and she is, following a long-standing traditional representation of the feminine body and female sexuality, naked, whose nudity is the sole pleasure for the eyes of the masculine creator, owner and eventual spectator.

This phenomenon is extended to other forms of visual representation which in its similarity produce the 'heterosexual division of labour' (Mulvey, 716) responsible for constructing the seer as the male subject and the one to be seen as the passive female body. 
According to Mulvey, the male figure's inability to 'bear the burden of sexual objectification' is transferred and accorded to the female body as the object of the gaze, an erotic spectacle that bears the masculine phantasy on itself, 'holds the look, plays to and signifies male desire'. (Mulvey, 716). The female body under this kind of oppressive machinery is depicted through its sexuality and its inert ability for sensual and visual excitation in men. The disciplines that construct a feminized body are tools used by the body's masculine creator as instruments of artistic reproduction. She is produced in order to appease the 'look' and is under the sovereign surveillance which results in subjecting her body as the central figure occupying the created spatial designs. Be it a sketched figure, a painted portrait, a novel's character or a body within the confines of the camera's frames - she is entrapped where she is created. Her performance within the narrative discourse becomes a state where she is dislodged into the territory inhabited solely by male reader/spectator's eyes. He surveils upon her movements, her activities, her meaning while she is forever encoded within the text as the erotic body that signifies phantasy. The body becomes available as a fetishistic object for the scopophilic gaze inside the frames of production. She functions, solely as a visual presence outside the contact of the linearity of the plot - 'as erotic object for the characters within the screen story, and as erotic object for the spectator within the auditorium' (Mulvey, 716); a phenomenon not restricted to the film language but is a translation of gendering the body to make it the erotic spectacle.

We can consider narrative literature to reduce the scope of representation - images are translated into words built on the patriarchal tradition where the author, predominantly male, writes for the presumably masculine reader. Whereas the erotic is coded into visual and cinematic language, textual narrative can go as far as to define the body, a definition restricted to trials; an author can script the body, clothe it, stripe it, but only to the point that language allows him. The limitations put on him by language regulates him within the boundaries of rhetorical structuring that he himself creates. It is within these boundaries that the feminine body is constructed, communicated and canonized as the signifier of the erotic. A reader's pleasure is derived from the process of uncovering or seeing the body get uncovered, stripped down to its skin. When the feminine body is covered with layers of clothing, 'more attention is directed to undressing it, and the more erotic investment is made ... in the undressing' (Brooks, 105). If the body is a 'cultural product' (Grosz, 23), gendering it would be to subject it within the prevalent discourse that asserts the feminine body with the cultural qualities associated with it. As Grosz argues:

The surface of the body, the skin, moreover provides the ground for the articulation of orifices, erotogenic rims, cuts on the body's surface ... create a kind of "landscape" of that surface, that is, they provide it with "regions," "zones," capable of erotic significance; they serve as a kind of gridding, an uneven distribution of intensities, of erotic investments in the body. (Grosz, 36)

As can be seen in Miller's creation of Ida Verlaine, her body is distributed into various stand-alone parts that signify and excite male desire - the small juicy cunt or the white ass are alienated from the body, as objects in itself, that in the cryptic masculine language of the erotic, marks the body as sexual. Miller calls to the reader's attention particular parts of the body while leaving out some. These parts of the body are regions or zones of erotic significance that invest the reader with an eroticway of seeing.

\section{CONCLUSION}

The female body, as a gaze-object in narratives, occupies the field of vision as an image in itself, alienated from the plot or the space that the body inhabits. As Lynda Nead suggests, 'It (the female nude) is complete; it is its own picture, with inside, outside and frame.' (Nead, 1992, 19), giving the feminine body a wholeness that allows it to stably perform as the object of desire. In the cited examples, applying both Sartre and Foucault's theories of the gaze allow us to illustrate how the erotic body is a result of the masculine gaze and is produced more as a commodity than an independent figure. While Sartre's phenomenology establishes sight as the primary source of sexual difference, Foucault's emphasis on the role of power further clarifies that in the postmodern, visual society, women's bodies function entirely as a codified language of desire under the male gaze in works of literature and cinema. In the body, gazed-upon, consciousness and self-presentation are, thus, left out; the seen body is contained, its sexuality mis-represented and the body is transformed into a commodified cultural product, all leading to the establishment of a sexual difference ruled by the binaries of representation. The fetishization of the body is driven by a perversion that comes from the pleasure of seeing - at one end of which is the masculine creator. The gendered feminine body is alienated as an object of desire inhabiting a space that is peculiarly constructed as masculine, with the overbearing masculine spectator, for whom, the female body is 
uncovered, stripped down, and sexualized for the eyes of the creator and the spectator. Thus, the female body, marked by its nudity in visual culture, is a play on various levels of aesthetic and erotic misrepresentation, drawn for the domestication and normalization of corporeity as the ideal cultural and social body of pleasure.

\section{REFERENCES}

[1] Barthes, Roland. 1975. The pleasure of the text. (Richard Miller, trans.). New York: Hill and Wang.

[2] Bartky, Sandra Lee. 1998. Foucault, Femininity and the Modernization of Patriarchal Power. In The politics of women's bodies: Sexuality, appearance and behavior, edited by Rose Weitz. New York: Oxford University Press.

[3] Beauvoir, Simone. 2011. The second sex. (Constance Borde and Sheila Malovany-Chevallier, trans.). New York: Vintage Books.

[4] Berger, John. 2008. Ways of seeing. New York: BBC and Penguin Books.

[5] Brooks, Peter. 1993. Body work: Objects of desire in modern narrative. Cambridge: Harvard University Press.

[6] Bryson, Norman. 1983. Vision and painting: The logic of the gaze. New Haven: Yale University Press.

[7] Buñuel, Luis, dir. 1977. Cetobscur objet du désir (That Obscure Object of Desire). France and Spain: Gaumont-La Gueville

[8] Butler, Judith. 1999. Gender trouble: Feminism and the subversion of identity. New York: Routledge.

[9] Campbell, Joseph. 1969. The hero with a thousand faces. New Jersey: Princeton University Press.

[10] Chow, Rey. 1992. Postmodern Automatons. In Feminists theorize the political, edited by Judith Butler and Jean W. Scott. London: Routledge.

[11] Collins, Margery L., Pierce Christine. 1980. Holes and Slime: Sexism in Sartre's Psychoanalysis. In Women and philosophy: Toward a theory of liberation. Edited by Carol C. Gould and Marx W. Wartofsky. New York: Perigree.

[12] Derrida, Jacques. 1987. The truth in painting. (Geoffrey Bennington and Ian McLeod, trans.). Chicago: University of Chicago Press.

[13] Dolezal, Luna. 2012. Reconsidering the Look in Sartre's Being and Nothingness. Sartre Studies International 18, no. 1: 9-28. http://www.jstor.org/stable/42705181.

[14] Dolezal, L. (2010). The (in)visible body: Feminism, phenomenology, and the case of cosmetic surgery. Hypatia 25(2), 357-375 https://doi.org/10.1111/j.15272001.2009.01075.x

[15] Foucault, Michel. 1991. The Foucault reader, edited by Paul Rabinow. New York: Penguin Books.

[16] Foucault, Michel. 1995. Discipline and punish: The birth of the prison. (Alan Sheridan, trans.). New York: Vintage Books.

[17] Freud, Sigmund. 2001. The Uncanny. In Literary theory: An anthology, edited by Julie Rivkin and Michael Ryan. Massachusetts: Blackwell Publishers.
[18] Freud, Sigmund. 1991. The Primacy of the Genital Zones and Fore-pleasure. In On sexuality: three essays on the theory of sexuality and other works. (James Strachey, trans.), edited by Angela Richards. United Kingdom: Penguin Books.

[19] Gilbert, Sandra M. and Gubar, Susan. 1979. The madwoman in the attic: The woman writer and the nineteenth-century literary imagination. New Haven: Yale University Press.

[20] Grosz, Elizabeth, 1994. Volatile bodies: toward a corporeal feminism. Bloomington: Indiana University Press.

[21] Hegel, G.W.F. 2018. The phenomenology of spirit. (Terry Pinkard, trans.). United Kingdom: Cambridge University Press.

[22] hooks, bell. 2014. Black looks: Race and representation. New York: Routledge.

[23] Irigaray, Luce. 1985. The speculum of the other woman. (Gillian C. Gill, trans.) New York: Cornell University Press.

[24] Irigaray, Luce. 1985. The sex which is not one. (Gillian C. Gill, trans.) New York: Cornell University Press.

[25] Joyce, James. 2004. A portrait of the artist as a young man and dubliners. New York: Barnes and Noble Classics.

[26] Kaplan, E. Ann. 1983. Women and film: Both sides of the camera. London: Routledge.

[27] Lerner, Gerda. 1986. The creation of patriarchy. New York: Oxford University Press.

[28] Lloyd, Genevieve. 1984. The man of reason. Minneapolis: University of Minnesota Press.

[29] Miller, Henry. 1965. The rosy crucifixion book I: Sexus. New York: Grove Atlantic.

[30] Millet, Kate. 1990. Sexual politics: The classic analysis of the interplay between men, women and culture. New York: Touchstone.

[31] Moi, Toril. 1989. Patriarchal Thought and the Drive for Knowledge. In Between feminism and psychoanalysis, edited by Teresa Brennan. New York: Routledge.

[32] Mulvey, Laura. 2009. Visual Pleasure and Narrative Cinema. In Film theory and criticism: Introductory readings. New York: Oxford University Press.

[33] Nead, Lynda. 1992. The female nude: Art, obscenity and sexuality. United Kingdom: Routledge.

[34] Rothman, William. 2001. That obscure object of desire. In The Criterion Collection. https://www.criterion.com/current/posts/169-that-obscureobject-of-desire

[35] Sartre, Jean-Paul. 1984. Being and nothingness: A phenomenological essay on ontology. (Hazel E. Barnes, trans.). New York: Washington Square Press.

[36] Snow, Edward. 1989. Theorizing the Male Gaze: Some Problems. Representations, no. 25: 30-41. doi:10.2307/2928465.

[37] Vidal, A. Sánchez. 1984. Luis buñuel: obracinematográfica [Luis Buñuel: Cinematographic Work]. Madrid: Ediciones J.C. 
[38] Williams, Linda. 1999. Hard core: Power, pleasure and the "frenzy of the visible". California: University of California Press.

[39] Woolf, Virginia. 1993. A room of one's own and three guineas. United Kingdom: Penguin Classics. 